\title{
INDONESIA SHARI'AH COMPLIANCE STOCK RETURN BEHAVIOUR
}

Vol. 15 - No. 1

April 2015

\author{
Helma Malini', Mohamad Jais', Rossazana Ab Rahim ${ }^{3}$ \\ ${ }^{1}$ Faculty of Economy, Tanjungpura University \\ ${ }^{1,3}$ Faculty of Economics and Business, University Malaysia Sarawak \\ 12helmamalini@yahoo.com, ${ }^{2}$ jmohamad@feb.unimas.my, ${ }^{3}$ arrossazana@feb.unimas.my
}

\begin{abstract}
This study aims to measures the behaviour of Indonesia Shari'ah compliance stock return. The measurement of return behaviour toward volatility will proved the capability of Indonesia Shari'ah compliance toward volatility that happened in Indonesia during the period of observation. Investing in Shari'ah compliance is quite different than investing in conventional stock which followed the capital market set of rules and law, Shari'a compliance follows not only the capital market set of laws and but also the Islamic principles of principles. Most of the previous studies examine issues related to the conventional stocks and market. The present study take one step further by investigating issue related to Shari'a compliance instrument. In the case of Shari'ah stock price in Indonesia, the dynamics volatility of the stock price can be minimized by taking an integrated screening process to the listed company, as precautions steps toward volatility.
\end{abstract}

Keywords: Indonesia Shari'ah compliance, Return Behaviour, Stock price, Stock Market Volatility

\section{INTRODUCTION}

The study of Efficient Market Hypothesis (EMH) related with the information availability and how market prices fully reflect all available information particularly price reaction toward news and events that known as stock return behaviour has evolved over the years. The evolution of these studies has contributed to the development of EMH as a theory into many concepts and areas of research interest. Several studies have focused on the role of EMH toward investor behaviour and stock return behaviour, such as return behaviour, seasonal anomaly, equity market integration and stock market volatility. These issues have many times been tackled by the researchers using conventional stock market background. Meanwhile, studies that focus on Islamic capital market are still limited and rare.

Islamic capital market has a number of diversifications in the implementations, such as Ijarah, Sukuk and Shari'ah compliance. This research focuses on Shari'ah compliance since it represents one of the biggest funding accumulations in Shari'ah financial industry besides Shari'ah banking. For the last Eleven years the growth of 
JURNAL

MANAJEMEN

INDONESIA

Vol. 15 - No. 1

April 2015
Shari'ah compliance has shown a major influence not only on capital market industries but also on the economic growth in one country. The distinguished feature of Shari'ah compliance that differentiate from the conventional stock market is the screening process of Shari'ah classified companies that is based on Shari'ah law or principle.

The most potential growth of Shari'ah compliances consists of three groups. Most of the asset accumulations are integrated in Gulf Cooperation Council ${ }^{1}$ (GCC) and Malaysia. The second group encompasses Islamic countries or countries with large Islamic populations. Indonesia is currently holding the biggest Muslim population with 174 million (85\%) of from 230 million of population (Indonesian Statistics Biro, 2013). The third group comes from European and US. These countries with their significant and relatively wealthy Muslim population are also potentially lucrative markets for Shari'ah compliances fund integration.

The measurement of Efficient Market Hypothesis is very important in Shari'ah compliance. In terms of market price, the stock price of classified company in Shari'ah compliance should reflect the real condition of the company which issues a stock. Meanwhile, the efficiency of Shari'ah compliance is believed to be the main factor that can be used in answering the market price problem in Shari'ah compliance. The efficiency of Shari'ah compliance refers to the condition where the price of stock fully reflects all available information. The process of creating market efficiency in Shari'a $h$ compliance begins with screening process, fair trading system and transparent information to all investor that invest their fund in Shari'ah compliance companies.

This research is very important to conduct since it will provide special treatment for the Shari'ah compliance in one side and realize the core concepts of Shari'ah compliance regulation and decide what the best concept for Shari'ah compliance in the future in order to achieve efficient market in term of fairness, transparency, protection to investor and reducing systematic risk.

\section{LITERATURE REVIEW}

During the period of observations (2000-2010), stock price in Indonesia stock exchange is very volatile due to several related factor. CPO price, interest rate and financial crisis are several related national issues that influence the volatility of Indonesia stock exchange. Since, conventional and Shari'ah compliance trading is integrated, makes the volatility of conventional stock market will also gives the same impact to Shari'ah compliance. Ginting (2011), trying to capture the volatility of Shari'ah stock price in Jakarta Islamic Index during the most volatile period in Indonesia stock exchange. National securities issues was one of the shocking event that gives the highest volatility to Shari'ah stock price in Indonesia, while monetary policy is giving less impact to the volatility since this events were categorize as public information and can be analyze by investor. The findings of Ginting suggested that investor in Jakarta Islamic index are rational investor based in responses and decision behaviour.

The measurement of stock return behaviour in Shari'ah compliance is very important to conduct to measure how volatile Shari'ah compliance stock price compared to conventional stock price. Shari'ah stock return behaviour will determine not only the pattern of volatility, but also pattern of risk, return and investor behaviour. Both Shari'ah compliances in Indonesia and Malaysia is vulnerable toward economic, political and social securities issues, research that focusing on the stock price volatility will only provide analysis to weak EMH, while

GCC s include Bahrain, Kuwait, Oman, Qatar, the United Arab Emirates, and Saudi Arabia 
research that focusing on the response of investor toward news and events will provide analysis about the stability of Shari'ah stock price to prevent investor for taking speculation or gambling activity (Ginting, 2011). Furthermore, a study of stock return behaviour in Indonesia and Malaysia will proves the stability of Shari'ah compliance stock price during crisis and other shocks in economy, since companies that classified in finance and banking industries are not allowed to be classified in the Shari'ah compliance because of interest rate implementation.

In Shari'ah compliance, stock return behaviour is a result from investor behaviour. Investors tend to response toward news and events in certain pattern that will influence Shari'ah compliance stock price. "Good" or "bad" news often forming "up" or "down" trends in stock market. Stock return behaviour in Shari'ah compliance is an equilibrium price from supply and demand mechanism in stock exchange, where intrinsic value of stock price describes the present value from cash flow that should be received by investor in the future. Present value of stock price should represented risk and time of the stock price. When new information is arrive to stock market, investor will make adjustment by buying or selling the securities, resulting to changing of current price real value. On the contrary, uninformed investor in Shari'ah compliance, response with a delayed toward information either because the cost of acquiring information is high or information is unreliable. Therefore the relationship between prices and information flow in Shari'ah compliance may be non linear. Volatility of stock returns behaviour toward news and events also describing the availability of public information. The process of measuring stock return behaviour toward news and events is by examining time lag between how long information is available to stock price adjustment. In efficient market context, efficient information happened if stock market price change immediately and unbiased upon the arrival of new information (Gaunt, 2000; Lai, et al., 2003 and Lihara et al., 2004). The changing showed that the volatility of price through normal condition, seldom lead investor to earn abnormal profit (Meidawati and Harimawan, 2004). Several news and events is considered to have significant influence, particularly to stock return behaviour. Other than financial information, news and events in politics, economy and national securities issue will also reflected in stock price.

Beaulieu et al. (2006) used political risk as news events that affecting the return behaviour. The reason for choosing political risk is based on believed that political risk is not merely a national scale issues but also considered as international scale issues that will affecting domestic and foreign investor. The result stated that uncertainty around political news events gives short run influence to stock return. Beaulieu et al. (2006) confirms that stock market was directly influenced by the political risk and uncertainty, it is implies that every political policy announcement creates abnormal returns to share holders depends on period of stock price adjustment.

Ardi et al. (2011) examines overreaction toward stock value by stressing on the phenomenon of stock value reversal that bring negative return for same period of time and then move toward positive return, on the other hand high-return stocks for while become worse and stock value go down. The result showed that market overreact signed loser portfolio exceed winner portfolio in 2005, after that both of groups stock value movement quite stabile. Triani (2011) analyze the influence of macroeconomic factors through volume of transactions, exchange rates, and interest rates of Jakarta Islamic Index. Fundamental reason for choosing interest rates as one of the variables is based on the major objective of investor is to gain

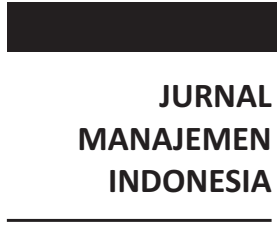

Vol. 15 - No. 1

April 2015 
JURNAL

MANAJEMEN

INDONESIA

Vol. 15 - No. 1

April 2015 profit or margin from their investment showed by the sharing of interest rate particularly for banking industry. The result showed that there is influence from macro economy variables such as interest rate and transaction volume towards Jakarta Islamic Index, where the influence of interest rate to Jakarta Islamic Index is more significant compared to volume of transaction, meaning that the increasing in interest rate will also increase companies expenditure to fulfill debt and lowering the level of profitability, while level of profitability is one of the main factor that can decrease or increase stock price of a company in stock market. In other concept, interest rate will also influence investor preferences of selecting investment portfolio. The higher the interest rate, the more investor preferences goes to banking industry, while the lower the interest rate, the more investor preferences goes to capital market (Sitinjak and Kurniasari, 2003).

\section{RESEARCH METHOD}

\subsection{Data}

This Section offers a brief description of the research method and the data set, using daily closing price of Indonesia Shari'ah compliance from the period of 2000: 1 to 2010: 12. Since Indonesia stock market has experienced major structural changes with the potential for affecting market efficiency, we divide our chosen sample period into three following sub periods of differing market stages:

1. January 1,2000-December 29, 12004 periods during its early stages of Indonesia Shar'iah compliance. In the early stages showed that many turbulences influence the establishment of shari'ah indices in both countries especially in term of policy and socialization.

2. January 1, 2005 - December, 29, 2008 periods during which the Indonesia Shari'ah compliance stock market grew significantly in size and number. The growth of Indonesia Shari'ah compliance because Indonesia has implemented and formulated socialization process.

3. January 1,2009-December, 29, 2010 periods after market crash. The period after market crash showed that Shari'ah compliance in Indonesia reluctant to several crises that happened in specially the subprime mortgage crisis in United States of America and in Europe.

\subsection{Methodology}

\section{Testing the Assumption of linearity}

Interest toward non-linearity and chaotic processes increased after a large movement of stock price because of severe crisis and stock market crash (Hsieh, 1990). The indication of large movement in stock market in term of capital has triggered unanticipated decision toward news and events particularly news and events with a huge shock and impact to stock market. As a form to challenging EMH and forecasting stock price movements, chaos and non-linearity observed the chaotic toward a large movement of stock price due to response of "bad or good" news. However, the assumption of nonlinearity is limited in financial time series, particularly in term of autocorrelation-based procedures in testing the weak-form EMH. According to Patterson and Ashley (2000), 'Successful non-linear time series modeling will improve forecasts and produce a richer notion of business cycle dynamics than linear time series models allow. For this to happen, two conditions are necessary. First, economic time series must contain non-linearity. Second, 
reliable statistical methods to summaries and understand the non-linearity that is suitable for time series of the typical macroeconomic length. Hinich and Patterson (1989) stated that several early researchers failed to assume the observed time series that is generated from Gaussian process and testing for white noise using correlation structure, thus making the ignoring possible non-linear relationships between consecutive price changes. Independent and identically distributed (i.i.d.) increments areas of white noise (i.e. serially uncorrelated), but the converse is not true unless the series is normally distributed. From a statistical perspective, the distinction between white noise and pure white noise is nontrivial when non-linear dependence is present.

There are number of studies that focus on non linearity in emerging markets.McMillan (2001) find evidence that stock market returns follow a non-linear dynamic system particularly in term of the relation with macroeconomic variables and financial variables due to the movement of small and large returns. Harrison and Moore (2012) found similar evidence that emerging market move with the same pattern of volatility, thin trading and low liquidity followed a nonlinear dynamic system. In the implementation, nonlinearity occurs in many statistical form, the five statistically test are; Mcleod and Li (1983) and Engle (1982) test for (G) ARCH), Brock et al. (1996) BDS test for randomness, Tsay's (1986) test for threshold effects and the Hinich and Patterson (1995) and Hinich (1996) bi-covariance test.

\section{Volatility Modeling}

Modeling and forecasting stock return volatility is central to modern finance because risk volatility increased due to market uncertainty and the attempt from market participant to manage asset pricing, asset allocation and risk management. Two approaches generally used are the GARCH and stochastic volatility (SV) models. In their standard forms, the ensuing volatility processes are stationary and weakly dependent with autocorrelations that decrease exponentially (Lu and Perron, 2009).

Arguably, volatility, as measured by standard deviation or variance of returns where there is a dispersion of returns for a given security or market index. Volatility clustering and leptokurtosis are commonly observed in financial time series (Mandelbrot, 1963). The idea of explicitly modeling time variation in second or higher order moments began only in the early 1980s; The autoregressive conditional hetersocedastic ARCH (Engle, 1982).

\section{RESULT AND DISCUSSION}

\section{Preliminary Evidence: AR (p) Model}

An AR $(p)$ model was fitted to the returns of Indonesia Shari'ah compliances to ensure the pre-whiten residual before testing the evidence of non linearity. Stock market returns are of the modeled as autoregressive time series with random disturbances having conditional heteroscedastic variances, particularly with GARCH type processes. This research are analyzing two data sets of stock prices, fitting an AR $(p)$ model to the series by ordinary least squares regression yielded the results in Table 1
JURNAL

MANAJEMEN

INDONESIA

Vol. 15 - No. 1

April 2015 


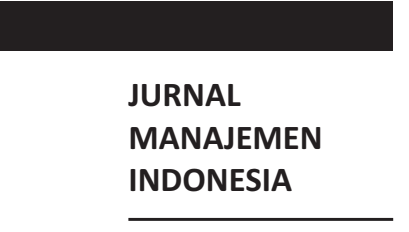

Vol. 15 - No. 1

April 2015

\begin{tabular}{cc}
\hline$\mu$ & Indonesia \\
\hline 1 & $0.191(42)$ \\
$\phi 2$ & 0.1033 .756 \\
$\phi 3$ & - \\
$\phi 4$ & 0.1809 .230 \\
$\phi 5$ & 0.0542380 \\
$\phi 7$ & 0.19199 \\
$\phi 8$ & 0.10366 \\
$\phi 10$ & 0.039207 \\
$D W$ & 0.014153 \\
$B . G(5)$ & 2.017035 \\
$L B Q(12)$ & $0.73[0.424]$ \\
$L B Q(24)$ & $2.13[0.621]$ \\
\hline & $12.121[0.761]$ \\
\hline
\end{tabular}

Table 1.

AR (p)

Pre-Whitening MODEL

(Indonesia Shari'ah Compliances)
Table 2.A

Nonlinearity Test on AR (p)

Residuals
Notes: *, **, and *** indicates significance at $10 \%, 5 \%$ and $1 \%$ levels respectively, $\mu$ is the constant. $\phi$ indicate the AR coefficients. B.G. is Breusch-Godfrey test for higher order serial correlation; D. W is the Durbin-Watson test for autocorrelation; LBQ (12), LBQ (24) indicates the Ljung-Box statistics for 12 and 24- lags respectively. Test statistics are shown in ( ) while p-values are shown in [ ].

Shari'ah compliances in Indonesia following the low order autoregressive with general assumption that Indonesia is follows the AR (1) process. Having fitted an AR $(p)$ model, it is now necessary to examine an adequate and useful functional form for the data generating process. To eliminate of spurious autocorrelation, AR $(p)$ also has a function to investigated, fitting and examined whether the nonlinear dynamics are localized in time. In the case of Shari'ah stock price in Indonesia, the dynamics volatility of the stock price can be minimized by taking an integrated screening process to the listed company, as precautions steps toward volatility.

\begin{tabular}{ccccc}
\hline Item & \multicolumn{2}{c}{ Indonesia } & \multicolumn{2}{c}{ Malaysia } \\
\hline & Asymptotic & Bootstrap & Asymptotic & Bootstrap \\
McLeod-LI (20 & 0.000 & 0.000 & 0.017 & 0.017 \\
lags) & & & & 0.000 \\
$\begin{array}{c}\text { McLeod-Li (24 } \\
\text { lags) }\end{array}$ & 0.000 & 0.000 & & 0.000 \\
Bicovariance (17 lags) & 0.000 & 0.000 & 0.000 & 0.005 \\
\hline
\end{tabular}


Engle LM

\begin{tabular}{rllll}
1 & 0.000 & 0.000 & 0.000 & 0.000 \\
2 & 0.000 & 0.000 & 0.000 & 0.000 \\
3 & 0.000 & 0.000 & 0.000 & 0.000 \\
4 & 0.000 & 0.000 & 0.002 & 0.005 \\
5 & 0.000 & 0.000 & 0.000 & 0.000 \\
Tsay & 0.000 & 0.000 & 0.010 & 0.002 \\
\hline
\end{tabular}

\begin{tabular}{lccl}
\hline Dimension & \multicolumn{3}{c}{ Indonesia } \\
\hline & EPS $=1$ & EPS=2 & $\begin{array}{l}\text { EPS=5 } \\
\text { Bootstrap }\end{array}$ \\
2 & & & 0.000 \\
3 & 0.000 & 0.000 & 0.000 \\
4 & 0.000 & 0.000 & 0.000 \\
2 & 0.000 & 0.000 & Asymptotic \\
3 & & & 0.000 \\
4 & 0.000 & 0.000 & 0.000 \\
\hline
\end{tabular}

The existence of linearity in Indonesia Shari'ah compliances showed that Shari'ah compliances in Indonesia is open for gaining abnormal return, where in the case of Shari'ah principle, gaining abnormal return is prohibited or against the principle of Shari'ah. Moreover, the existence of linearity in Shari'ah compliance also showed the capability of predicts returns and lead to inefficiency in Shari'ah compliance, since information are not available to all Shari'ah compliance participant. On the other hand, follower investor tends to reacts quickly to information based on their belief that following other investor reaction is the best investment decision. The mentality of following other investor decision will create higher transaction cost and lazy investor. Higher transaction cost is occurs due to the implication of undistributed information while lazy investor occurs due to the implication of waiting other investor to make decision. Such behaviour often occur in emerging market like Indonesia and the implication for Shari'ah compliance is that this action is against the principle of Shari'ah compliance, which is transparency, fairness, support risk sharing and equal distribution of information.

\section{CONCLUSION}

The existence or non existence of nonlinearity in Shari'ah compliance is crucial not only for Shari'ah compliance as portfolio but also for investor to determine appropriate strategy for trading. For example, if Shari'ah securities follow nonlinear behaviour, than it may not be profitable for investor to use linearity based on trading strategies. Furthermore, nonlinearity test are very effective tools that can be used as diagnostic test to explore and understand the nature of the underlying dynamics in stock returns.
JURNAL

MANAJEMEN

INDONESIA

Vol. 15 - No. 1

April 2015
Table 2B.

BDS Test on AR ( $p$ ) Residuals 


\section{REFERENCES}

JURNAL MANAJEMEN INDONESIA

Vol. 15 - No. 1 April 2015
Ardi, A. Kiryanto, and Amalia, D., (2008), Overreaksi Pasar Terhadap Harga Saham Perusahaan- Perusahaan di Indonesia (Studi Kasus pada Bursa Efek Indonesia). Simposium Nasional Akuntansi (SNA) ke XI.

Beaulieu M. C., Jean C. C., and Naceur E., (2006), Political Uncertainty and Stock Market Returns: Evidence from the 1995 Quebec Referendum, Canadian Journal of Economic, 39 (2): 621-641.

BPS., (2013), Statistical Yearbook of Indonesia, various issues, Badan Pusat Statistik, Jakarta.

Brock, W.A., W.D. Dechert, J.A. Scheinkman and B. LeBaron., (1996), A test for independence based on the correlation dimension, Econometric Reviews 15, 197235.

Engle, R.F., (1982), Autoregressive conditional heteroscedasticity with estimates of the variance of United Kingdom inflation, Econometrica 50(4), 987-1007.

Ginting, J. (2011), Model Realized Volatility Untuk Seleksi Saham Pada Jakarta Islamic Index di Indonesia, Journal of Economics and Bussiness, Vol 1, No 1).

Gaunt, C. (2000) Overreaction in the Australian Equity Market: 1974-1997, Pacific Basin Finance Journal, 375-398.

Harrison, B. and Moore W., (2012), Stock Market Efficiency, Non-Linearity, Thin Trading and Asymmetric Information in MENA, Economic Issues, Vol. 17, Part 1.

Hinich, M.J. and D.M Patterson, (1995), Detecting epochs of transient dependence in white noise, mimeo, University of Texas at Austin.

Hinich, M.J., (1996), Testing for dependence in the input to a linear time series model, Journal of Nonparametric Statistics, 6, 205-221.

Lai, M.M., Guru, B.K., and Fauzias, M.N., (2003), Do Malaysian investors overreact?, Journal of American Academy of Business, 602.

Lihara, Y., Kato, H.K. and Tokunaga, T., (2004), The Winner-loser Effect in Japanese Stock Returns, Japan and the World Economy, 471-485.

Lu, Y. K. and Perron P., (2009), Modeling and Forecasting Stock Return Volatility Using a Random Level Shift Model, Department of Economics, Boston University, 270 Bay State Rd., Boston, MA, 02215.

Mandelbrot, B., (1963), The variation of certain speculative prices, The Journal of Business 36(4), 394-419.

McLeod, A. I. and Li, W. K., (1983), Diagnostic Checking ARMA Time Series Models Using Squared-Residual Autocorrelations, Journal of Time Series Analysis 4, 269-73.

Mcmillan, G.D., (2001), Nonlinear predictability of stock market returns: Evidence from nonparametric and threshold models, International Review of Economics and Finance 10 (2001) 353-368.

Meidawati N,. and Harimawan, M., (2004), Pengaruh Pemilihan Umum Legislatif Indonesia Tahun 2004 Terhadap Return Saham dan Volume Perdagangan Saham LQ-45 di PT. Bursa Efek Indonesia (BEJ), SINERGI Kajian Bisnis dan Manajemen, Vol 7 No. 1, 89101.

Patterson, D. M. and Ashley, R. A., (2000), A Non-linear Time Series Workshop, Kluwer Academic, London.

Sitinjak, E.L.M dan Kurniasari. W., (2003), Indikator-Indikator Pasar saham Dan Pasar Uang yang Saling Berkaitan Ditinjau Dari Pasar Saham Sedang Bullish dan Bearish, Jurnal Riset Ekonomi dan Manajemen, vol.3 no.3.

Triani L.F., (2011), Faktor Faktor Yang Mempengaruhi Perubahan Indeks Harga Saham di Jakarta Islamic Index Selama tahun 2011, Jurnal Organisasi dan Manajemen, Volume 9, Nomor 2, September 2013, 162-178.

Tsay, Ruey S., (1986), Nonlinearity Tests for Time Series, Biometrika 73, 461-6. 